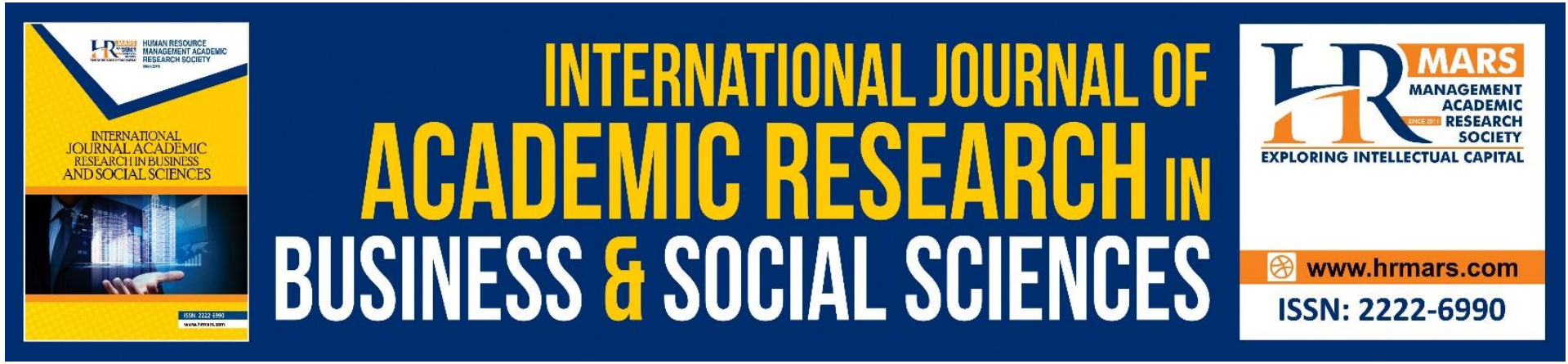

\title{
An Overview on Medical Property Contents of Gac Fruits and Overview on Medical Property Contents of Gac Fruits Scientifically and Type of Fruits in Al Qur'an Perspective
}

Ahmad Shabudin Ariffin, Ramisah Mohd. Shah, Khalilullah Amin Ahmad, Anis Jazilah Azmin @ Che Wan

To Link this Article: http://dx.doi.org/10.6007/IJARBSS/v11-i7/10514

DOI:10.6007/IJARBSS/v11-i7/10514

Received: 21 May 2021, Revised: 23 June 2021, Accepted: 12 July 2021

Published Online: 25 July 2021

In-Text Citation: (Ariffin et al., 2021)

To Cite this Article: Ariffin, A. S., Shah, R. M., Ahmad, K. A., \& Wan, A. J. A. @ C. (2021). An Overview on Medical Property Contents of Gac Fruits and Overview on Medical Property Contents of Gac Fruits Scientifically and Type of Fruits in Al Qur'an Perspective. International Journal of Academic Research in Business and Social Sciences, 11(7), 579-587.

Copyright: @ 2021 The Author(s)

Published by Human Resource Management Academic Research Society (www.hrmars.com) This article is published under the Creative Commons Attribution (CC BY 4.0) license. Anyone may reproduce, distribute, translate and create derivative works of this article (for both commercial and non-commercial purposes), subject to full attribution to the original publication and authors. The full terms of this license may be seen at: http://creativecommons.org/licences/by/4.0/legalcode

Vol. 11, No. 7, 2021, Pg. 579 - 587

Full Terms \& Conditions of access and use can be found at http://hrmars.com/index.php/pages/detail/publication-ethics 


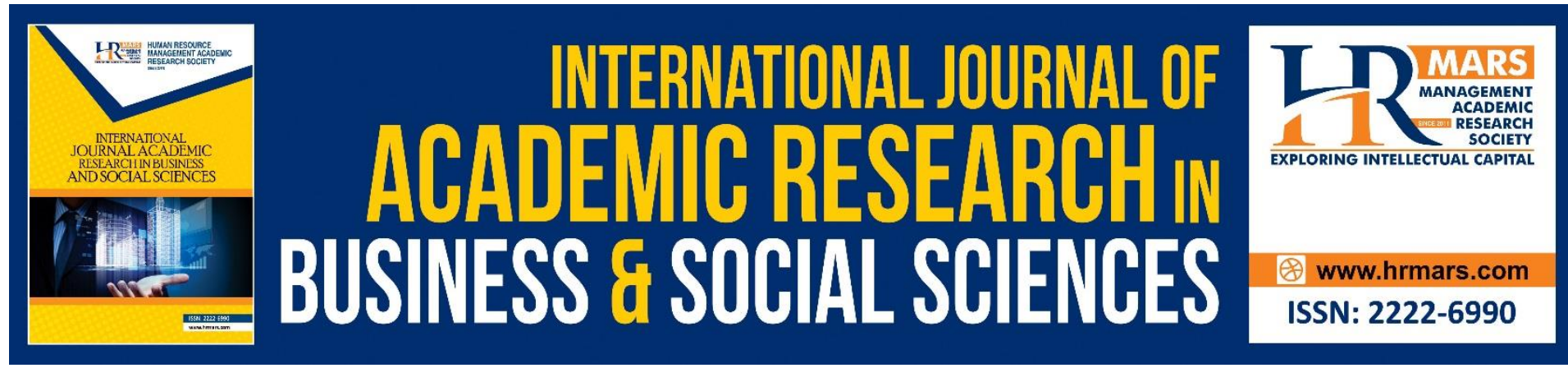

\title{
An Overview on Medical Property Contents of Gac Fruits and Overview on Medical Property Contents of Gac Fruits Scientifically and Type of Fruits in Al Qur'an Perspective
}

\author{
Ahmad Shabudin Ariffin \\ Kolej Universiti Islam Perlis (KUIPs) Malaysia \\ Ramisah Mohd. Shah \\ Universiti Malaysia Terengganu (UMT) Malaysia
}

\author{
Khalilullah Amin Ahmad, Anis Jazilah Azmin @ Che Wan \\ Kolej Universiti Islam Perlis (KUIPs) Malaysia
}

\begin{abstract}
This review aimed to gather the details about the fruits mentioned in the Qur'an. The fruits that exist in the Qur'an are the establishment and creation of Allah the Highest and the Wisest. It can be well-founded that the use of fruits in the Qur'an has their own importance through various aspects, both in terms of benefits and health. It has already been explained by previous scholars and it is still continued to be researched. Results of the diversity of bioactive compounds underlie the potential use and application of medical property as an excellent source of dietary supplements. Fruits that are found to be rich in multiphytochemicals are being considered as 'super' fruits due to their unique antioxidants. Gac fruit (Momordica cochinchinensis Spreng), is one of those 'super' fruits found to be rich in phytonutrients because of its portions such as aril, seeds, pulp and peel which have been widely used in folk healing and ancestral medicine. But, the entire potentiality towards the health benefits of Gac fruit is not well known or understood. Importantly, Gac fruit contains significantly higher amounts of lycopene and relatively high levels of $\beta$-carotene. The findings from this review suggest that the phytochemicals found in Gac fruit especially carotenoids and their potential health benefits.
\end{abstract}

Keywords: Gac Fruit, Biomedical, Carotenoids, Medical Property, Phytochemicals.

\section{Introduction}

The Qur'an is the greatest miracle revealed to our great Prophet, the Prophet Muhammad SAW in the unique Arabic language. It contains a variety of the greatest secrets and wonders that have been the focus and relevance of all time. All the rules and methodologies enshrined in it become a source of lifestyle for believers until the Day of Judgment (Zulkepli, 2016). The discussion on the fruits mentioned in the Qur'an has already 
been explained by previous scholars and it is still continuing through numerous researches. The scholarly studies of this particular topic have been described by scholars and it has been discussed in various angles and perspective. The examples of its references are from these sources; Kitab al-Nabat (1974), al-Thimar wa al-A'syab al-Waridah fi al-Qur'an al-Karim wa alSunnah al-Nabawiyyah (2006) and Asrar al-Nabat (2009). There is no specific surah in the Quran that explains the fruit of Gac (Momordica Cochinchinensis). This fruit, which originated from Vietnam, is still not very popular in Malaysia. However, its nutritional content is very useful for human health. Gac fruit has a mixed aroma of melon and carrots with a slightly bland taste. What makes Gac fruit special is its various properties in maintaining a healthy body.

This fruit is often said to be a super food because it has a higher content of Vitamin C than citrus fruits. The lycopene content of this fruit is also more than that of tomatoes. And the beta carotene content in it is more abundant than in carrots.

\section{Types of Fruits in the Qur'an}

The results of the studies by many researchers found that there are verses of the Qur'an that are recorded containing the words fruits such as Tin (al-Tin), olive (al-zaitun), banana (Talh), grape ('Inab), pomegranate (al-Rumman) and dates (al-Nakhl).

\section{Fig (Ficus carica L)}

Tin fruit or fig is recorded by Allah SWT in the Qur'an as He says:

وَالزَّْتُونِن

Meaning: "For the sake of figs and olives."

(Surah al-Tin: 95: 1)

According to Ibn al-Manzur (1999), the word al-Tin refers to the fig tree and a hill located in Syria. In fact, the miracle behind this fig is a truth conveyed through His messengers. Fig contains cleansing substances that can heal wound by means of rubbing it on the outside of the body (Khasanah, 2011). According to Sumaiyah (2015), fig or fig tree (Ficus carica) is a plant from the family Moraceae and it comes from West Asia and the Mediterranean East. The characteristics of this fig fruit are; the tree has deciduous leaves, reproduces quickly in its habitat area, the tree trunk is not dense and easily broken wood, the height of the tree is in the range of 3 to 10 meters different according to genotype. In addition, the United States Department of Agriculture states that figs contain a variety of ideal nutrients such as vitamin A, vitamin C, calcium, magnesium and potassium. The advantage of eating this fruit is to control the appetite and to help with the weight loss efforts. Fig juice is also the best drink to kill bacteria that do not benefit the body (Khasanah, 2011).

Al-Zuhaili (2009) once explained that Allah SWT started surah al-Tin with a curse on the country that is famous for figs and olives. The figs and olives mentioned in the verses of the Qur'an are parables of the country that is famous for both. Allah SWT has sworn to this fig tree because it is a kind of fruit and a cure for various diseases. The properties of this fruit are soft and it can help speed up the digestive process. The content of this fruit can be used as an antidote because it works to treat and remove waste products in the body. According to Qadah (2009), it is a kind of fruit that is famous in the Quran. The secrets and wonders behind this fruit have been explored by ancient scholars. Fig fruit contains elements of protein, phosphate, iron, vitamins, carbohydrates and calcium. From a medical point of view, it helps to produce hemoglobin for those who suffer from red blood cell deficiency (anemia). In addition, among the benefits of figs are that they can help prevent constipation and 
facilitate bowel movements in the body. Among the specific nutrients and benefits of this fruit is that it can help to reduce the shortness of breath, cleanse the liver and spleen and remove accumulated phlegm. It is also seen as a preventive measure to fight toxins and bacteria in the body. In addition, the presence of nutrients such as fiber, potassium and magnesium in fig fruit can reduce stroke and can provide control over high blood pressure for people with high blood pressure. For diabetics, fig fruit can slow down the process of absorption of glucose (sugar) in the small intestine.

\section{Olives (Olea europea L)}

Olives are revealed by Allah SWT in the Qur'an as He says:

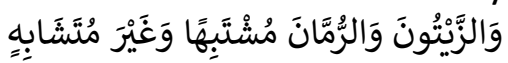

Meaning: "... And olives and pomegranates, which have similarities in form, appearance and taste and which do not have other similarities (color or leaves)."

(Surah al-An'am: 6: 99)

Abadi (2005) explains that al-Zaitun refers to an olive tree, a mosque in the city of Dimasyq or a hill in Syria. While Ibn al-Manzur (1999) stated that the word Al-Zait is oil produced from olives.

Scientifically, Sumaiyah (2015) mention about Olea europaea L or it is better known as olive. It comes from Phenicia which is the southern part of the Arabian Peninsula. The olive tree is important in the culture of the Mediterranean community because according to the beliefs of their cultural traditions, it is a symbol of peace. It is based on the events of the pigeons sent to check the flood level during the time of US Prophet Noah. Then, he returned with olive tree twigs in the beak of the bird. Among the Jews, olive oil is traditionally applied to the whole body before a person participated in a self-defense mission. During the Christian era, the olive tree became a symbol of Holy Spirit. Spain is the largest producer of olive oil with 180 million olive trees grown from Andalusia to Catalonia. According to Katsoyannos (1992), the olive tree is a tree of the Oleaceae family of the medium size. The stem is rough, straight and elliptical. The leaves are grayish green. The fruit is berry-shaped and produces slightly white flowers. Generally, olives are resilient trees that grow in mountainous, rocky and even arid areas where most other plants cannot survive. In the scientific world, olives bear the scientific name Olea europaea which still belongs to the family Oleaceae. The olive tree is a long-lived tree for more than a hundred years and even thousands of years. It produces fruit continuously without any influence from humans. Olives in various studies are believed to have many benefits and specialties, from the stem, leaves to the fruit. The content in olives is very complex such as high levels of protein, nutrients and antioxidants, as it has salts that contain calcium, iron, and phosphate. These are the essential substances needed by the human body. In addition, almost all olives can be used as an anti-infection of internal organs such as kidneys, bile and contain colloidal compounds that can kill cancer cells.

Al-Zuhaili (2009) explains in his interpretation that Allah SWT is the creator of everything in this world. Every plant, fruit and the like is also included in His creation. Allah SWT created each plant from various types of shapes, appearances, characteristics, properties and tastes. Similarly, Allah SWT's creation, olives and pomegranates also mentioned by Him to contain similarities and differences in color or leaves. Every plant created is born from the same water sources and comes from the same type of soil. However, the difference for each crop is the smell, taste, color and maturity of the plant according to the suitability of the climate and human needs. Thus, this is proof of God's absolute power and cannot be disputed at all. From the medical point of view, it turns out that olives contain antioxidant agents. 
Based on a study made by Cicerale (2010), it is found that the content of phenolic compounds in olive oil can protect the oxidative damage of DNA. DNA oxidative damage is a trigger to carcinogenesis and leads to the development of cancer cells. Moreover, studies show that olive oil intake during breakfast significantly reduces F2-isoprostanes compared to breakfast that is not enriched with phenolic compounds. F2-isoprostanes are a sign of oxidative stress. Oxidative stress produced by reactive oxygen species that can cause various diseases such as arteriosclerosis, cancer and diseases of the nervous system.

\section{Bananas}

Bananas are also stated by Allah SWT in the Qur'an as He says:<smiles>[Mg][Mg][Mg]</smiles>

Meaning: "And banana trees that are well arranged (the fruit)".

(Surah al-Waqi'ah: 56:29)

Ibn al-Manzur (1999) mentions that the word Talh has two meanings. First, the tree that grows in the Hijaz area is from the species of al-Sumurah tree (acacia tortilis) and it is known as Ummu Ghailan tree. The characteristics of this banana tree are large, leafy and green leaves and have fine thorns that grow in rough soil.

Based on the verses of the Qur'an, Wahbah al-Zuhaili (2009) explains that it is among the blessings of heaven received by its inhabitants. They enjoy the beauty of heaven full of lasting delights. It is stated to be among the thorny bidara trees. They can see that in the paradise there are trees of paradise, namely banana trees that are neatly arranged fruit and river water that flows continuously. According to al-Hadi (1998), the banana tree in the verse is a reflection of the blessings of heaven received by His faithful servants. Everything is available for the inhabitants of heaven which adds to the pleasure of both the physical and sight. Accordingly, it can be said that bananas are one of the wonders and pleasures of heaven created by God. It becomes the inner ornament of heaven for the faithful and pious. From this discussion, it can be seen that the comparison between the words Talh and banana (alMauz) according to the context of the verses of the Quran. The word Talh in the Quran describes the fruit created for the inhabitants of paradise. The tree is large, tall and has many leaves. It has green leaves and is a place to shelter under it. The fruit is prepared for the inhabitants of heaven and they can have fun lying under the shade of this tree. While al-Mauz shows it is a banana that is the food of various people.

\section{Grapes (Vitis vinivera L)}

Grapes are mentioned by Allah SWT in the Qur'an as He says:

وَعِنَبَا وَقَضْبًا

Meaning: "... And grapes and vegetables..."

(Surah 'Abasa: 80: 28)

The word 'Inab according to al-Fairuz Abadi (2005) is the plural word for grapes. Similarly Ibn al-Manzur (1999) stated that the single term for grape is 'Inabah while the double words are al-'Inab, A'nab and al-'Inaba'.

Sumaiyah (2015) explains that the scientific name for the grape is Vitis vinifera L. It has a strong stem with a height of 2 meters. The stems are rough and fuzzy. The leaves of the vine are single leaves i.e. one leaf grows on one stalk. The leaves are between 10-16 cm long and 8-14 cm wide. The leaves grow alternately, the surface rough and the edges serrated. However, it depends on the specific type of grape. There are many tendrils that serve as support to the stalks. 
According to Wahbah al-Zuhaili (2009), the essence of the verses of the Qur'an explains a call to human beings to appreciate how Allah SWT made their food to for them live on this earth. Thus, it is an indication to humans that the food that exists on this earth has its own sources. It consists of various produces such as cereals, wheat, corn, grapes, vegetables and others. In other words, all the food products that exist on earth can be a source of sustenance to universal human life. Therefore, all these growing fruits are among the great blessings bestowed by Allah SWT on human beings. However, looking at the grapes mentioned, they contain nutrients and benefits. Mahir (2006) has stated that grapes provide benefits from a nutritional and medical perspective. Among the advantages of grapes are to facilitate the digestive process in the stomach, cleanse the blood, help balance the digestive process and cure for heart disease. According to Visioli et al. (2000), several clinical trials conducted found that consumption of foods containing phytochemicals such as anthocyanin found in grapes can reduce the risk of heart disease. So, it is clear here that grapes have benefits that are useful to human beings.

Pomegranate (Punica granatum $\mathrm{L}$ )

The pomegranate is recorded by Allah SWT in the Qur'an as He says:

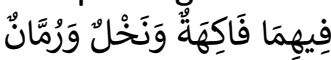

Meaning: "... In both there are also fruits, as well as palm and pomegranate trees."

(Surah al-Rahman: 55: 68)

According to lbn al-Manzur (1999), the word al-Rumman is a plural word and it refers to a kind of fruit which is pomegranate. From a scientific point of view, Sumaiyah (2015) mentioned that the pomegranate is known as Punica granatum L. It is a plant from the family Punicaceae. The pomegranate tree comes from Iran. Later, it was grown throughout the Mediterranean to India, China and the United States (California). Currently, pomegranate trees are found in almost all tropical and subtropical regions. However, these plants do not bear fruit well in areas that are too moist. High quality fruit is obtained from areas where the winter is moderate and the summer is hot and dry.

Al-Zuhaili (2009) is of the view that there are various types of fruit that exist in heaven. Among them are dates and pomegranates. In the context of this verse, the Qur'an states that these two fruits contain their own nutrients and benefits compared to other fruits. Both fruits are classified as noble fruits when compared to other fruits. This is because dates and pomegranates are certified as fruit which is a source of food and cure. The medical world proves that pomegranates can be used as a cure for diabetes. Bagri (2009) has conducted a study on pomegranate flowers and found that the flowers can be used as a supplement in treating chronic diseases caused by failure of glucose metabolism. In fact, it can also be used as prevention for diabetes. Therefore, there is no denying that the nutrients in pomegranates are indeed useful and can help humans.

This coincides with the view of Ibn Kathir (1998) in his commentary that mentions that pomegranates and dates are mentioned specifically because of the glory found in both fruits compared to the other. Al-Maraghi (1964) explains that although both fruits are included in the category of fruits, but the term specifically gives an indication of the advantages they have. He stated that among the special features of pomegranate is that it is available in summer and winter. In fact, it can also be made into staple food or be eaten alone. From this description, it is clear that the specialty of pomegranates and it coincides with the concept of specialization enshrined in the verses of the Qur'an. 
Dates (Phoenix dactylifera L)

Dates are stated in the Qur'an as Allah SWT says:

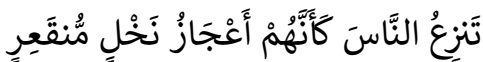

Meaning: "The ones who overthrew the fallen human beings, as if they were the trunks of palm trees exposed."

(Surah al-Qamar: 54: 20)

According to Ibn al-Manzur (1999), the word al-Nakhl refers to the palm tree. The cultivation of date palms dates from 6000 to 8000 years ago in Mesopotamia. At that point, it is likely that no other plants were planted anywhere. Therefore, palm trees are closely related to human culture and civilization. Amer (1994) states that the height of the palm tree is between 15 to 25 meters, the cross-sectional radius is between 20 to 40 centimeters and the roots reach 6 meters deep. The trunk of a palm tree consists of strong cellulose fibers and can be used in producing plywood. The leaves of palm trees are usually in the range of 3 to 6 meters depending on the type and leaves that live between 3 to 7 years.

Abu (2012) explains that dates have been known since time immemorial. It is also recorded in the Gospels and the Torah. It became the food of the Prophets and Messengers. There are almost 100 types of palm trees. Modern scientists have listed nearly 200 nutrients of dates that can benefit human health. Dates are not only to be eaten but other parts of this fruit can be utilized. Among them is date flower powder which is used as a food supplement as an alternative to obtain offspring and it is also squeezed to produce oil. According to lbn Kathir (1998), the verses of the Qur'an describe the people of 'Aad who lived in the time of the Prophet Hud. They denied their apostle as the people had done before them. The culmination, God sent down a disaster on them that was a very strong storm that was very cold and destroyed them. The storm that befell them overthrew all the people on that day and they were scattered from their sight. The view of Ibn Kathir (1998) is further strengthened by the view of Wahbah al-Zuhaili (2009) who mentioned that the strong storm that punished the people of 'Aad destroyed them from the face of the Earth. They crumbled and fell to the surface of the Earth in a state of dying.

\section{Scientifically medical property in Gac Fruit (Momordica Cochinchinensis)}

Ripe gac fruit has a reddish orange color, due to its high beta carotene and lycopene content. Both of these ingredients are antioxidants that can protect body cells from damage caused by free radicals. Because of its ability to fight free radicals, gac fruit is also good for consumption to prevent cancer. The human body can convert beta-carotene into Vitamin A. Because of the high levels of beta-carotene contained in gac fruit, this fruit can prevent or treat various diseases caused by lack of Vitamin A. A body that is deficient in Vitamin A is prone to various health problems. Some of them are visual disturbances, such as night blindness, cataracts, and decreased vision. Apart from vision problems, a deficiency of Vitamin A can also cause problems with digestion, skin, and make the body weaker to fight infection. Gac fruit can help maintain the body's immunity because this fruit is rich in Vitamin $C$, which is known to help boost the immune system. By doing this it will increase the productions of white blood cells, as well as antibodies that help fight viruses and bacteria in the body. That way, your body also doesn't get sick easily.

Premature aging can appear at the age of 20-30 years, marked by the appearance of changes in skin pigment to look duller, dry and sagging skin, and the appearance of wrinkles on the forehead and eye area. Antioxidants contained in this fruit have the ability to maintain skin elasticity and elasticity. This makes the skin firmer, healthier and fresher. Apart from 
preventing premature aging, gac fruit is also good for maintaining overall skin health. This fruit acts as an anti-inflammatory and helps accelerate healing of injured skin.

According to the research conducted by Huynh et. al (2018) in the article Biomedical Importance of Momordica Cochinchinensis (Gac) Fruit and Future Applications; there are a few key findings. Momordica cochinchinensis (Lour.) Spreng is geographically restricted to tropical climates predominantly in Southeast Asia with wild populations both genetically and morphologically diverse (Wimalasiri, Piva \& Huynh, 2016), Vernacular names throughout Australasia to Europe suggest its historical significance and widespread occurrence Lim but its importance was often downgraded by the majority of the community as a common and inexpensive food crop. Scientific validation has highlighted and elevated the importance of the fruit and has rejuvenated the crop for future developments locally and internationally. The aril of $M$. cochinchinensis contains the highest levels of nutritionally important carotenoids of all known fruits and vegetables, with more than 150 and 200 times the level of lycopene and $\beta$-carotene than that found in tomatoes and carrots, respectively Gul et al (2017).

\section{Conclusion}

The fruits that exist in the Qur'an are the creation of Allah the Highest and the Wisest. It can be concluded that the use of fruits in the Qur'an has their own importance through various aspects both in terms of benefits and health. Based on the Qur'an, there are many fruits mentioned in it which is one of the signs of His greatness. With the natural discovery of medical property from $\mathrm{M}$. cochinchinensis, it is very useful in our society as a biomedical and biomolecular for the future. The increasing use of Gac products in health, cosmetics and personal care suggests new ways to deliver these nutrients and bioactives.

\section{Acknowledgement}

This paper and the research behind it would not have been possible without the exceptional support from Kolej Univesiti Perlis and Universiti Malaysia Terengganu. To those who have also looked over our research and answered with unfailing patience numerous questions about the scientific and the spiritual questions that we have. To Kolej Universiti Islam, Perlis, for giving us the opportunity to come together and to pool our ideas together for this paper. The generosity and expertise of one and all have improved this study in innumerable ways and saved us from many errors; those that inevitably remain are entirely our responsibilities.

\section{Corresponding Authors}

Ahmad Shabudin Ariffin

Senior lecturer Faculty of Business \& Management Science Kolej Universiti Islam Perlis (KUIPs) Malaysia

Email: shabudin@kuips.edu.my

\section{References}

Abadi, M.-F. M.-D. (2005). Qamus al-Muhit. Beirut: Dar al-Jil.

Abdel, A. M., Akhtar, H., Zaheer, K., \& Ali, R. (2013). Dietary Sources of Lutein and Zeaxanthin Carotenoids and Their Role in Eye Health. Nutrients 5(4), 1169-1185.

Al., V. F. (2000). Diet and prevention of coronary heart disease: the potential role of phytochemicals. Cardiovascular Research. Vol 47, No 3.

Al-Hadi, A.-M. (n.d.). 'Alam al-Nabat fi al-Quran al-Karim. Qaherah: Dar al-Fikr al-'Arabi. 
Ali, F., Rahul, Naz, F., Jyoti, S., \& Siddique, Y. H. (2017). Health functionality of apigenin: A review. Int J Food Prop 20(6), 1197-1238.

Al-Maraghi, A. (1946). Tafsir al-Maraghi. Egypt: Mustafa al-Babi al-Halabi wa-Awladuh.

Al-Quran. (2001). Tafsir Pimpinan al-Rahman kepada Pengertian al-Quran. Kuala Lumpur: Jabatan Kemajuan Islam Malaysia (JAKIM).

Al-Zuhaili, W. (2009). Tafsir al-Munir fi al-'Akidah wa al-Shari'ah wa al-Manhaj. Dimashq: Dar al-Fikr.

Bagri, P. (2009). Antidiabetic effect of Punica granatum flowers: Effect on hyperlipidemia, pancreatic cells lipid peroxidation and antioxidant enzymes in experimental diabetes. Food and Chemical Toxicology. Vol 47, No 1.

Gul, K., Tak, A., Singh, A., Singh, P., Yousuf, B., \& Wani, A. (2015). hemistry, encapsulation, and health benefits of carotene - A review. Cogent Food \& Agriculture, 1(1).

Huynh, T. (2018). Biomedical Importance of Momordica Cochinchinensis (Gac) Fruit and Future Applications. Biomedical Journal of Scientific \& Technical Research, 8(4).

Ibn al-Manzur. (1999). Lisan al-'Arab. Beirut: Dar Ihya' al-Turath al-'Arabi.

Katsoyannos, P. (1992). Olive Pest And Their Control In The Near East. Rome: Food And agriculture Organization Of The United Nations.

Khasanah, N. (2011). Kandungan Buah-Buahan Dalam Al-Quran: Buah Tin (Ficus carica L), Zaitun (Olea europea L), Delima (Punica granatum L), Anggur (Vitis vinivera L), Dan Kurma (Phoenix dactylifera L) Untuk Kesehatan. Jurnal Phenomenon 1(1).

Mahir, M. H. (2006). al-Thimar wa al-A'syab al-Waridah fi al-Quran al-Karim wa al-Sunnah al-Nabawiyyah. Egpyt: Dar al-Nada.

Ali, M. A. (2012). al-Nabatat fi Al-Quran. Qaherah: Dar al-Islam.

Qadah, A. (2009). Asrar al-Nabat. Dimashq: Dar al-Ghauthani li al-Dirasat al-Quran al-Karim.

Tamizi, S. M. (2015). Tumbuhan Terpilih Menurut Perspektif Islam Dan Sains Kesihatan. . Kuala Lumpur: Universiti Malaya.

Wimalasiri, D., Piva, T., \& Huynh, T. (2016). Diversity in Nutrition and Bioactivity of Momordica cochinchinensis. International . Journal on Advanced Science, Engineering and Information Technology, 6(3), p.378. .

Zulkepli, M. (2016). Buah-Buahan Dalam Al-Quran Menerusi Aspek Bahasa Arab. Bangi: Universiti Kebangsaan Malaysia. 